\title{
Factors Affecting Credit Card Debts: A Study among Executives in Sri Lanka
}

\author{
Chandana Perera ${ }^{1}$, S. L. Kasun Dayanga ${ }^{2}$, Nisha Jayasuriya ${ }^{3}$ \\ ${ }^{1}$ Professor and Dean, Faculty of Business, Sri Lanka Institute of Information Technology, New Kandy Road, Malabe, Sri Lanka \\ ${ }^{2}$ IT Manager, Bank of Ceylon, BOC Square, Bank of Ceylon Mawatha, Colombo 01, Sri Lanka
}

${ }^{3}$ Lecturer, Faculty of Business, Sri Lanka Institute of Information Technology, New Kandy Road, Malabe, Sri Lanka

\begin{abstract}
This study explores credit card revolving debt and credit card instalment debt behaviours among credit card holders and examines how demographic and socio economic factors, attitude factors, personality factors and security factors influenced revolving credit and instalment plan of credit cards and discerned the specific roles of each kind of factors. The study was conducted by using online mail-in questionnaires, which were sent to credit card holders who was using or had used either revolving credit or instalment plans. The findings of this research indicate respondent's debt behaviour is influenced by demographics and socio economics variables are significantly. Going depth further, it proves that the Females preference for security improve the credit card transitions. Moreover, females who have distrust characteristics would be a heavy revolver or heavy instalment plan consumers than males. Another finding of this research says Age above 35 years are using credit card daily for power and prestige. People who use credit cards more than 5 years, have less usage indicates that people would not frequently consume credit cards long time.
\end{abstract}

Keywords: Card holder, Revolving debt, Instalment debt, Debt behaviour, Attitudes, Personality, Credit card security

\section{Introduction}

Credit card has become a vital payment tool for consumers all over the world, both in the developed and developing countries. During the year 2007, credit card use in the Asia Pacific region stood at $\$ 1.3$ trillion, which was 30 percent of global credit card transactions (Brito and Hartley, 1995).With the fast growth of credit card use, credit card debt has grown exponentially in both developed and developing countries.

In Sri Lanka, the total number of credit cards in use amounted to $1,115,299$ at the end of September 2015. As a developing country it is vital to find out reasons for credit card debt, as it is very much convenience(Hirschman1979) and painlessness (Gurugamage and Wickramasinghe, 2009), there is big opportunity to growth the credit card debt in future.

The study of credit cards debt in a developing country, such as Sri Lanka, also helps to highlight and provide insights into the phenomenon of globalization. The methods used by credit card companies in penetrating the Sri Lankan market can be examined to see if their approach has been global and to identify the necessary modifications. Therefore, thorough understanding of the credit card debt is very important from the point of view not just of the banker, but also point of view of the card holder and other relevant parties who involve in the credit card business.

Although the credit card industry is lucrative business in the developed countries, there is low growth in some countries including Sri Lanka. In Sri Lanka, the credit card industry is more than two decades old. Credit cards were introduced to Sri Lanka after the concept of free and open economy. Within the framework of transition from a controlled economic environment to an export-oriented, free market economy, Sri Lanka provides the opportunity to examine the introduction and the acceptance process of credit cards.

In Sri Lanka, traditional attitudes like „save first and spend latereec might negatively affect the growth of credit card consumption. When analyzing the other fast developing Asian countries, adoption to credit card debt has become significant, such as South Korea and China. According to the data provided by the People"s Bank of China, credit card issuers $^{\text {e }}$ mass-mailed over 18.6 million credit card offers in mainland China in 2009, an increase of 30.4\% compared to previous year. In South Korea, credit card debt rose to $14 \%$ of the GDP in 2009. In Taiwan, the almost 7 million people have become ,,,redit card slaves" ${ }^{\prime \prime}$,which account for almost $6 \%$ of economic population. Meanwhile, credit cards, along with guns and drugs, are regarded as the big three poisons in Taiwan(Lili Wang, 2011).

Situation in neighbour countries like India and Pakistan credit card market penetration has been weaken in recent years. In Pakistan, the market remains unsaturated and a low number of cardholders exist as compared to other developing countries (Afshan, Ayesha and Madiha, 2009). In India, credit card use remains limited to 2\% penetration (Emerging Markets Payment (2015). The credit card market in India had witnessed a steady growth in the late 1980s andearly 1990s, but currently stands stagnant. Japan led Asian region in total transactions made through credit cards (\$209 billion), followed by South Korea ( $\$ 203$ billion). The total transaction made through credit cards in India was merely $\$ 2$ billion; meanwhile USA has recorded significant $\$ 793.1$ billion credit card debts in this year(Arpita, Anshuman, and Shveta, 2011).

Although Credit cards were introduced by western country, currently has widespread all over the world as easy payment device. In the western part of the world there are number of researches had been done regarding credit cards, but there are

\section{Volume 5 Issue 7, July 2016}




\section{International Journal of Science and Research (IJSR) \\ ISSN (Online): 2319-7064}

Index Copernicus Value (2013): 6.14 | Impact Factor (2015): 6.391

very few evidence found from Sri Lanka (Gurugamage and Wickramasinghe, 2009).

To explore the credit card debt among Sri Lankan credit card consumer, and find the influential factors for credit card debt, will generate new knowledge, which will be very much useful for all the relevant parties involving credit card business.

Therefore the objectives of research are,

1) To identify social, socio-economic and attitudinal and personality factors related to credit card users.

2) To explain influential factors affecting credit card debt behaviour.

3) To provide suggestions for the decision makers to the policy decisions

\section{Literature Review and Hypothesis}

Extant literature segments credit card users into two different groups, convenience users and revolvers. Convenience users are paying full amount of credit card bill when they receive the credit card statement (Garcia, 1980). Revolvers pay only an interest charges on unpaid balances (Kwon and Lee, 2002,).Revolvers use credit cards as mode of financing (Kwon, Lee, 2002) and they compete with other financial loans (Afshan et al. 2009).

Demographic variables, Economics variables, psychological variables could account for $66 \%$ of the variance in personnel debt (Livingstone and Lunt 1992). Lack of financial knowledge was the strongest predictor to the debt.The number of credit cards, attitudes towards the possessions and spending, delay of gratification, and credit card use habit uniquely predicted debt but demographic variables with the exception of age, sensation seeking, materialism, and student attitudes towards debt were not predictive of credit card debt(Norvilitis, Szablicki, and Wilson, 2003).

A lot of researchers have claimed that psychological factors including personality variables (Norvilitis et al. 2003) and attitude variables are the most important predictors of the level of debt and debt behaviour(Livingstone and Lunt 1992).The absolute amount of debt was meaningless (Tokunaga, 1993) as the absolute amount of debt is cumulative (Norvilitis et al. 2003).Therefore it cannot represent the level, intensity, or severity of debt. Therefore using outstanding balance of credit card is useless. Some researchers use debt-to-income ratio as dependent variable(Chie and, Devaney, 2001).

Grieb and Jones(2001) chose to address credit card payment problems directly, specifically by examining credit cards delinquency rates. Over the period from 1981 through 1999, this paper investigated the relationship between bankcard delinquencies and key macroeconomic variables-credit supply, capacity to service debt, job market conditions, and interest rates. Changes in the proportion of accounts in default are statistically related to the consumer debt ratio. When the delinquency rate is calculated based on the number of dollars outstanding, it is related to the total amount of revolving debt. This study reported evidence consistent with a pattern of selective default behaviour, in which consumers will default on credit card debt before defaulting on other types of instalment loans.

When considering demographic variable, disposable income was positively related to the amount of debt (Livingstone andLunt 1992). Family income had a negative effect on the amount of debt. Higher the one scored on financial knowledge, the more debt one owned (Robb and Sharpe, 2009).For attitude variables, some of the research claims that credit card attitudes could positively predict the amount of debt. Debtors have several risk factors, including knowledge, personal expectations about future income, and attitudes toward money and spending. Thus, solving the problem of credit-card debt will require more than just a brief informational session. Credit-card debt clearly impacts students ${ }^{e e}$ psychological well-being and stress levels and improving the piece on self-control, as research has indicated that self-control may be improved with exercise (Norvilitis et al. 2003).

Arpita et al. (2011)stated credit use was influenced by demographic and economic factors. Marital status and professional status were positively related to instalment debt. But, home ownership was negatively related to instalment debt. Education was positively related to credit card debt as hypothesized. Household size, marital status, and professional status were positively related to credit card debt. Income was negatively related to credit card debt. These results should help consumers and consumer educators better understand the role of attitude toward using credit. Consumer educators should help consumers to understand the importance of their attitudes toward credit if the consumers are attempting to change behaviour resulting from charging too much or having difficulty in paying regularly and on time. Educators may need to help consumers distinguish between general and specific attitudes and to help them focus on the decisions involved in obtaining an instalment loan or charging with a credit card. Also same study indicate that a favourable general attitude toward using credit has a positive effect on predicting the amount of instalment loans, and favourable specific attitude toward using credit has a positive effect on predicting the amount of the credit card balance.

Payment behaviour was used as debt measurement (Chien andDevaney, 2001), (Robb and Sharpe, 2009). Frequency of revolving credit card use and frequency of petty cash instalment debt can be taken in to analyze credit card debt and also provides meaningful implications for credit card debt management (Lu, Malhotra and Wang, 2010,pp. 179193).

Gurugamage and Wickramasinghe, (2009) stated that in Sri Lanka, use of credit cards for day-to-day expenses and credit card spending on durables are low. In Sri Lanka, females tend to pay medical expenses more than males. Single respondents significantly tend to pay more for eating out/entertainment than married respondents. Level of education is also significant in making payments for utility bills and mortgage, and eating out/entertainment, where highly educated respondents spend more on utility bills and mortgage while less-educated respondents spend more on eating out/entertainment. With regard to payment practices, the percentage of Overall, the findings suggest that very high

\section{Volume 5 Issue 7, July 2016 www.ijsr.net}




\section{International Journal of Science and Research (IJSR) \\ ISSN (Online): 2319-7064 \\ Index Copernicus Value (2013): 6.14 | Impact Factor (2015): 6.391}

percentage of respondents across all demographic and socioeconomic strata tend to use credit card as a mode of financing and elect to pay interest charges on outstanding credit card balances. Further, consumers ${ }^{\text {ee }}$ attitudes towards credit card debt have changed considerably, and individuals tend to see credit cards as a convenient and relatively painless way of spending, and that debt has become more socially acceptable.

Norvilitis et al. (2003)stated that in China, self-control, selfesteem, self-efficacy, were negatively related to the frequency of revolvingcredit use. People who scored high on one or some of these variables normally can manage their financial account, and, they will control their behaviour by avoiding carrying too much debt, when their financial situations go worse. Meanwhile, compulsiveness was positively related to frequency of revolving credit use. It is because those who score higher on compulsiveness are less likely to be able to resist temptation, so they are often indulgent in shopping and spending. Furthermore for instalment debt, thrill and adventure seeking dimension of sensation seeking, and experience seeking dimension of sensation seeking were selected. The thrill and adventure seeking dimension, and the experience seeking dimension of sensation seeking were positively related to the frequency of petty instalment use. Those who score high on these dimensions are more likely to take risky behaviour at the expense of carrying debt.

Christen and Morgan, (2005) showed that rising income inequality has substantially contributed to increased consumer borrowing. Income inequality affects all components of total household debt, but the impact is strongest on non-revolving debt (instalment loans), which is used to finance the purchase of consumer durables. They argue and provide evidence that the income inequality effect on consumer borrowing is a result of conspicuous consumption. Rising income inequality has forced households with smaller income gains to use debt to keep up their consumption level relative to households with larger income gains.

Lu at el. (2010) stated that in China, money attitudes, debt attitudes influenced revolving credit debt and instalment debt. Power prestige dimension of money attitude positively related to the credit card debt, the retention dimension of money attitude negatively related to the credit card debt. Debt attitude was positively related to the frequency of revolving credit use. People, who take a positive attitude towards debt, normally think borrowing money or carrying some debt is not so bad and that it is not a big deal. In order to live better, they would like to use revolving credit more. Furthermore, for instalment debt, debt attitudes were positively related to the frequency of instalment use. Retention dimension of money attitude were negatively related to the frequency of instalment debt.

Chakravorti(2003) statedcredit cards provide consumers a secure, reliable and convenient means of payment. Consumers often receive incentives to use their credit cards such as dispute resolution services, frequent-use awards, and interest-free short-term loans if no balances are carried between billing periods. Credit cards also provide various security features and limit consumer liability in the event of fraudulent use.

Based on above literature, hypothesizes of research developed,

H1a: Revolving cards affect to credit card debt

H2a: Instalment plan affects to credit card debt

H3a: Power - prestige of money affects to attitude of card holder

H4a: Retention of money affects to attitude of card holder H5a: Distrust of money affects attitude of card holder H6a: Debt attitude of money affects to attitude of card holder

\section{Conceptualization}

Present research work related to credit card debtare grounded from west. In Sri Lanka there arelimited research evidenceson credit card users ${ }^{\text {ee }}$ debt behaviour and its influential factors. Credit card debt behaviour is represented by two dependent variables, which are revolving credit debt behaviour and instalment debt behaviour. As independent variables, attitudes, personality factors, credit facility features and Utility factors are included. Security feature in credit facility and merchant options are author defined independent variables. Although attitudes and personality factors were measured based on standard research papers questions, some questions were altered to relate with Sri Lankan culture. As demographic variables, age, gender, education level, income, profession and civil status are taken as moderating variables.

\section{Questionnaire}

Questionnaire was developed based on six parts.

Table 1: Organisation of Questionnaire

\begin{tabular}{|r|l|}
\hline Context & Description \\
\hline Part 1 & $\begin{array}{l}\text { Credit card debt behavior identified using revolving } \\
\text { and instalment payment behavior. }\end{array}$ \\
\hline Part 2 & $\begin{array}{l}\text { Attitude factors identified based on money attitude and } \\
\text { Debt attitude }\end{array}$ \\
\hline Part 4 & Credit card security features \\
\hline Part 5 & Merchant options \\
\hline Part 6 & $\begin{array}{l}\text { Demographic factors - age, gender, and civil status, the } \\
\text { highest level of education, monthly income and no of } \\
\text { credit cards, and length of credit cards use }\end{array}$ \\
\hline
\end{tabular}

Source: Author

Revolving debt behaviour and Instalment plan -6 items on a five-point Likert scale ranging from (1) ,Never happen ${ }^{\text {ee }}$ to (5),Almost Every month ${ }^{\mathrm{ee}}$.

Money attitude - 10 items on a five-point likert scale ranging from (1) ,Never"e to (5), Always ${ }^{\text {ee }}$.

Debt attitude -6 items on a five-point likert scale ranging from (1) ,Strongly disagree " to (5) ,Strongly Agree”. Self-control -5 items on a five-point likert scale ranging from (1) ,Not at all like me ${ }^{c e}$ to (5) „Very much like me. Self-esteem -5 items on a five-point likert scale ranging from (1) ,Strongly disagree " to (5) „Strongly Agree”. Sensation seeking - 5 items on a five-point likert scale ranging from (1) „Strongly disagree "e to (5) „Strongly Agree”. Merchant options - 5 items on a five-point likert scale ranging from (1), Never happen ${ }^{\text {ee }}$ to (5), ,Always '.

\section{Volume 5 Issue 7, July 2016 www.ijsr.net}




\section{International Journal of Science and Research (IJSR) \\ ISSN (Online): 2319-7064}

Index Copernicus Value (2013): 6.14 | Impact Factor (2015): 6.391

Security features -5 items on a five-point likert scale ranging from (1) ,Strongly disagree "e to (5). „Strongly Agree”.

No of credit cards, Length of credit card use, credit limit are nominal variables.

In addition, questions were asked to collect demographic data on age, Gender, and civil status, the highest level of education, monthly income.

The questionnaire was piloted with a random sample of 15 customers that fit with the intended sample of the study prior to the distribution. It should be noted that this research is conducted as an independent study for academic purposes. Therefore, the questions in the questionnaire were designed by the authors based on internationally published research papers, and those did not address specific organizational interests. Further, participants were briefed on the aims of the study prior to data collection, and their responses were anonymous. Data were analyzed using the SPSS software. In addition to descriptive statistics, independent samples $t$-test, factor analysis, correlation were used to analyze the data set.

\section{Sample}

The sample of the study is restricted to individuals who possess a credit card issued by a financial institution that allows the cardholder to utilize the card for payments and as a source of revolving credit and instalment credit. A structured questionnaire is used as the research instrument. Questionnaire was online filled and distributed through e mailing by sharing the URL. As sampling strategy, nonprobabilityself-selection sampling was selected, 163 credit card holders who works as executives in Colombo metropolitan area, participated the survey.The survey took approximately 20 minutes to complete.

\section{Results}

More than $35 \%$ of the subjects were female. More than $78 \%$ of the subjects were younger than age 35 . More than $89 \%$ of the subjects had a bachelor's degree. The majority of subjects had a monthly income greater than Rs. 50,000 Most of the subjects were Married (72\%) and younger than age 34(78\%).

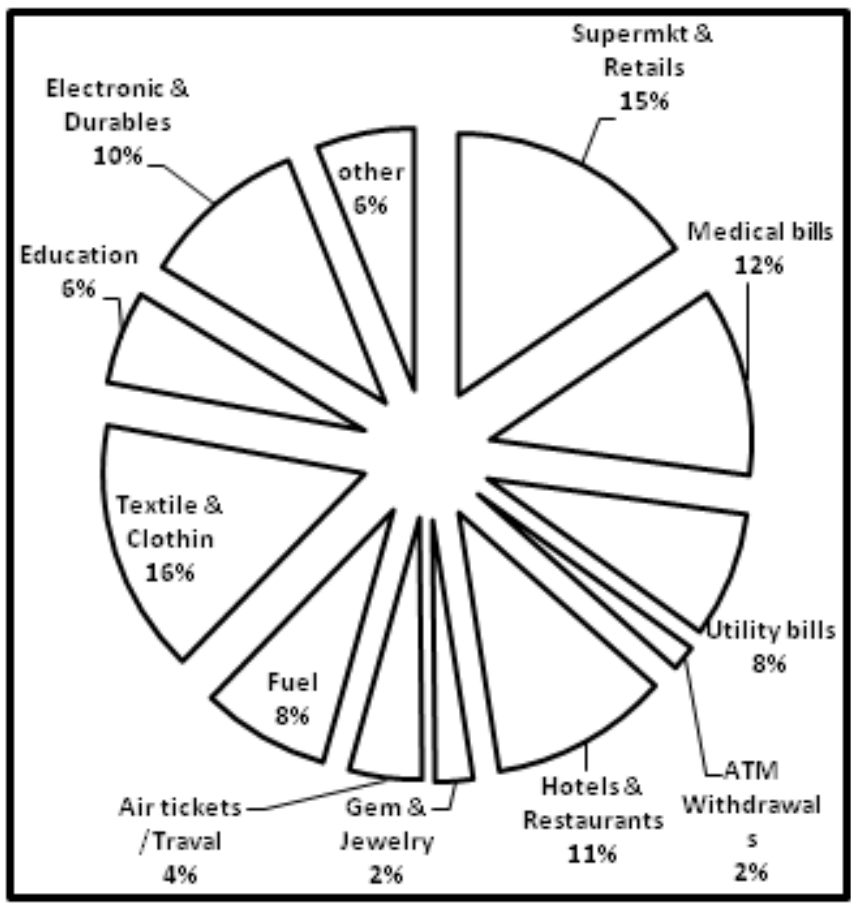

Figure 1: Credit Cards Acquiring at Merchant Categories Source: Survey summary data, 2013

For the credit card acquiring, super market/retails shops and textiles/clothing merchantse holds highest acquiring percentage, which is $15 \%$. Figure 1 shows the market percentage of each merchant category. $63 \%$ of males and $52 \%$ of females are frequently users of credit cards to purchase goods from super markets and retails shops. $60 \%$ of males $64 \%$ females are frequently users of credit cards to purchase textiles and clothing. Withdrawal money from ATMs is the lowest acquiring usage, which is $2 \%$ from total credit card acquiring.

Reliability test was done for the raw data which were considered as critical factors. According to the result given by SPSS software, Cronbach's alpha was positive for all factors. Table2 indicates the relevant questions numbers of each factor and Cronbach's alpha of each factor. Validity of factors is analyzed by factor analysis. Table3-Table6 shows the variances of each factor. Hypothesis analysis for factors tabulated in Table7. Mean weighted value on the all the factors are hypothetically significant, where the entire alternative hypothesis are accepted. Therefore it reflects respondents have revolving debt and instalment debt behaviours. Further, power-prestige, retention, distrust and debt attitudes effect to psychology of card holders and selfcontrol,self-esteem and sensation seeking factors effect to personality of card holders. Significance of data was analyzed both statically and hypothetically, and conclusions were made accordingly. Table 8 shows all the factors were statically significant. Revolving debt behaviour, instalment debt behaviour, power-prestige, retention, debt attitude, selfcontrol, self-esteem, sensation seeking, security and merchant options are statically significant at 0.01 levels. Instalment debt is statically significant at 0.05 confidence level. Therefore it reflects respondents have revolving debt and instalment debt behaviours. Further, power-prestige, retention, distrust and debt attitudes effect to attitude of card 


\section{International Journal of Science and Research (IJSR) \\ ISSN (Online): 2319-7064 \\ Index Copernicus Value (2013): 6.14 | Impact Factor (2015): 6.391}

holders and self-control, self-esteem and sensation seeking factors effect to personality of card holders.

Correlation between debt behaviour and other independent variables are tabulated in Table9. It shows revolving debt is correlating with retention and distrust at the 0.01 level. These show although card holders have revolving debt behaviour, they tend to saving money for future usage.

Table 2: Cronbaches alpha for factors

\begin{tabular}{|c|c|}
\hline Factors & Cronbach's alpha \\
\hline Revolving Debt & $\mathbf{0 . 7 0 2}$ \\
\hline Instalment debt & $\mathbf{0 . 7 8 2}$ \\
\hline Power- prestige & $\mathbf{0 . 7 0 2}$ \\
\hline Retention & $\mathbf{0 . 7 7 6}$ \\
\hline Distrust & $\mathbf{0 . 7 2 4}$ \\
\hline Debt attitude & $\mathbf{0 . 7 2 8}$ \\
\hline Self-control & 0.35 \\
\hline Self-esteem & 0.44 \\
\hline Sensation seeking & $\mathbf{0 . 7 8 3}$ \\
\hline Merchant Options & $\mathbf{0 . 7 7 8}$ \\
\hline Security & $\mathbf{0 . 7 1 8}$ \\
\hline
\end{tabular}

Source: Data Analysis

Table 3: Factor analysis, debt behaviour of credit card users

\begin{tabular}{|c|c|c|}
\hline Element & $\begin{array}{c}\text { F1- } \\
\text { Revolving } \\
\text { Debt }\end{array}$ & $\begin{array}{c}\text { F2- } \\
\text { Instalment } \\
\text { Debt }\end{array}$ \\
\hline A1 & 0.754 & \\
\hline A2 & 0.639 & \\
\hline A3 & 0.805 & \\
\hline A4 & 0.703 & \\
\hline A5 & & 0.909 \\
\hline A6 & & 0.909 \\
\hline $\begin{array}{c}\text { \% of } \\
\text { Variance }\end{array}$ & $\mathbf{5 2 . 9 8}$ & $\mathbf{8 2 . 6 6}$ \\
\hline
\end{tabular}

Source: Data Analysis
Table 4: Factor analysis, attitude factors of credit cards of credit card users

\begin{tabular}{|c|c|c|c|c|}
\hline Element & $\begin{array}{c}\text { F1- Power- } \\
\text { prestige }\end{array}$ & $\begin{array}{c}\text { F2- } \\
\text { Retention }\end{array}$ & $\begin{array}{c}\text { F3- } \\
\text { Distrust }\end{array}$ & $\begin{array}{c}\text { F4-Debt } \\
\text { Attitude }\end{array}$ \\
\hline B1 & 0.611 & & & \\
\hline B2 & 0.753 & & & \\
\hline B3 & 0.770 & & & \\
\hline B4 & 0.768 & & & \\
\hline B5 & & 0.830 & & \\
\hline B6 & & 0.845 & & \\
\hline B7 & & 0.819 & & \\
\hline B8 & & & 0.771 & \\
\hline B9 & & & 0.851 & \\
\hline B10 & & & 0.782 & \\
\hline C1 & & & & 0.618 \\
\hline C2 & & & & 0.798 \\
\hline C3 & & & & 0.790 \\
\hline
\end{tabular}

Source: Data Analysis

Table 5: Personality factor of credit cards

\begin{tabular}{|c|c|}
\hline Element & F1- Sensation seeking \\
\hline F1 & 0.783 \\
\hline F2 & 0.783 \\
\hline F3 & 0.845 \\
\hline F4 & 0.752 \\
\hline \% of Variance & $\mathbf{6 1 . 6 3}$ \\
\hline
\end{tabular}

\section{Source: Data Analysis}

Table 6: Security factors of credit cards

\begin{tabular}{|c|c|}
\hline Element & F1- Security \\
\hline G1 & 0.701 \\
\hline G2 & 0.813 \\
\hline G3 & 0.719 \\
\hline G4 & 0.715 \\
\hline \% of Variance & $\mathbf{5 4 . 4 9}$ \\
\hline
\end{tabular}

Source: Data Analysis

Table 7: Hypothesis analysis results for factors

\begin{tabular}{|c|c|c|}
\hline Factor & Hypothesis & Result \\
\hline Revolving debt behavior & $\begin{array}{l}\text { H1o : Revolving cards not effect to debt behavior of card holders if U1 = Uh1 } \\
\text { H1a : Revolving cards effect to debt behavior }\end{array}$ & $\begin{array}{l}\text { H1o is rejected and H1a is } \\
\text { accepted }\end{array}$ \\
\hline Instalment debt behavior & $\begin{array}{c}\mathrm{H} 2 \mathrm{o}: \text { Instalment plan not effect to debt behavior of card holders if } \mathrm{U} 1=\mathrm{Uh} 1 \\
\mathrm{H} 2 \mathrm{a}: \text { Instalment plan effects to debt behaviour }\end{array}$ & $\begin{array}{l}\mathrm{H} 2 \mathrm{O} \text { is rejected and } \mathrm{H} 2 \mathrm{a} \text { is } \\
\text { accepted }\end{array}$ \\
\hline Power -prestige & $\begin{array}{c}\text { H3o : Power -prestige not effect to attitude of card holders if } \mathrm{U} 1=\mathrm{Uh} 1 \\
\text { H3a : Power -prestige effects to attitude }\end{array}$ & $\begin{array}{l}\text { H3o is rejected and H3a is } \\
\text { accepted }\end{array}$ \\
\hline Retention & $\begin{array}{c}\text { H4o : Retention not effect attitude of card holders if } \mathrm{U} 1=\mathrm{Uh} 1 \\
\text { H4a : Retention effects to attitude }\end{array}$ & $\begin{array}{l}\mathrm{H} 4 \mathrm{o} \text { is rejected and H4a is } \\
\text { accepted }\end{array}$ \\
\hline Distr & $\begin{array}{l}\text { H5o : Distrust not effect to attitude of card holders if } \mathrm{U} 1=\mathrm{Uh} 1 \\
\text { H5a : Distrust effects attitude }\end{array}$ & $\begin{array}{l}\text { H5o is rejected and H5a is } \\
\text { accepted }\end{array}$ \\
\hline Debt attitude & $\begin{array}{l}\text { H6o : Debt attitude not effect to attitude of card holders if U1 = Uh1 } \\
\text { H6a : Debt attitude effects to attitude }\end{array}$ & $\begin{array}{l}\text { H6o is rejected and H6a is } \\
\text { accepted }\end{array}$ \\
\hline Self-control & $\begin{array}{c}\text { H7o: Self-control not effect to personality if } \mathrm{U} 1=\mathrm{Uh} 1 \\
\text { H7a : Self Control effects to personality }\end{array}$ & $\begin{array}{l}\mathrm{H} 7 \mathrm{o} \text { is rejected and } \mathrm{H} 7 \mathrm{a} \text { is } \\
\text { accepted }\end{array}$ \\
\hline Self-esteem & $\begin{array}{l}\text { H8o : self-esteem not effect personality of card holders if } \mathrm{U} 1=\mathrm{Uh} 1 \\
\text { H8a : Self-esteem effects personality }\end{array}$ & $\begin{array}{l}\text { H8o is rejected and H8a is } \\
\text { accepted }\end{array}$ \\
\hline Sensation Seeking & $\begin{array}{c}\text { H9o : Sensation Seeking not effect to personality of card holders if U1 }=\text { Uh1 } \\
\text { H9a : Sensation seeking effects personality }\end{array}$ & $\begin{array}{l}\mathrm{H} 9 \mathrm{o} \text { is rejected and } \mathrm{H} 9 \mathrm{a} \text { is } \\
\text { accepted }\end{array}$ \\
\hline
\end{tabular}

Ux- Mean of Likert scale of factor x, Uxh- Mean of factor elements are calculated based on calculating respondents answer's values and finding the average on each factor.

Source: Author 


\section{International Journal of Science and Research (IJSR) \\ ISSN (Online): 2319-7064}

Index Copernicus Value (2013): 6.14 | Impact Factor (2015): 6.391

Table 8: Statically analyzed results for factors

\begin{tabular}{|c|c|c|c|}
\hline Factors & Mean & Standard Deviation & $p$ value \\
\hline Revolving debt & 3.5951 & 0.95791 & 000 \\
\hline Instalment debt & 3.4448 & 0.19479 & 000 \\
\hline Power- prestige & 2.4939 & 0.84435 & 000 \\
\hline Retention & 3.219 & 0.96955 & 000 \\
\hline Distrust & 2.9798 & 0.822294 & 000 \\
\hline Debt attitude & 3.2209 & 0.54152 & 000 \\
\hline Self-control & 2.6356 & 0.53422 & 000 \\
\hline Self-esteem & 3.4248 & 0.5714 & 000 \\
\hline Sensation seeking & 3.5184 & 0.78889 & 000 \\
\hline Merchant Options & 2.7129 & 0.63362 & 000 \\
\hline Security & 3.3215 & 0.04395 & 000 \\
\hline
\end{tabular}

\section{Source: Data Analysis}

Table 9: Correlation between revolving debt and influence factors

\begin{tabular}{|c|c|c|}
\hline Factor & Rev.Debt & Ins.Debt \\
\hline Power -prestige & -0.125 & -0.025 \\
\hline Retention & $.261^{* *}$ & -0.023 \\
\hline Distrust & $.210^{* *}$ & $0.166^{*}$ \\
\hline Debt attitude & -0.054 & $0.221^{* *}$ \\
\hline Self-control & -0.115 & 0.014 \\
\hline Self-esteem & -0.021 & 0.01 \\
\hline Senseeking & 0.07 & $0.209^{* *}$ \\
\hline Security & 0.087 & -0.100 \\
\hline
\end{tabular}

Source: Data Analysis

Distrust feature of money attitude correlate with revolving debt significantly, shows that card holders who could not trust financial translations, tends to use their credit cards and practice the revolving behaviour. Instalment debt is correlating with distrust, debt attitude and sensation seeking factors at $\mathrm{p}>0.01$ level.

Table10to Table 17) indicates the correlations between debt behaviour and independent variables based on demographic groups. Significant correlations are identified and discussed in conclusion.

Regression analysis is done for find out the impact of independent factors on debt behaviour and independents variables (security, debtattitude, distrust, sensation seeking, power, retention) could accounted $\left(\mathrm{R}^{2}\right)$ the $14.2 \%$ of revolving debt and $12.5 \%$ instalment debt. Impact of demographic, socio economic variables for debt behaviour is indicated at Table18. Impact of demographics, socio economics variables at credit card acquiring at merchant categories are indicated at Table19.

Table 10: Correlation between revolving debt and gender

\begin{tabular}{|c|c|c|c|c|}
\hline Factor & $\begin{array}{c}\text { Rev.Debt } \\
\text { Male }\end{array}$ & $\begin{array}{c}\text { Inst.Debt } \\
\text { Male }\end{array}$ & $\begin{array}{c}\text { Rev.Debt } \\
\text { Female }\end{array}$ & $\begin{array}{c}\text { Inst.Debt } \\
\text { Female }\end{array}$ \\
\hline Pow-prest & -0.145 & -0.091 & 0.361 & 0.083 \\
\hline Retention & 0.178 & -0.112 & 0.258 & 0.044 \\
\hline Distrust & $0.218^{*}$ & 0.046 & 0.641 & $0.389^{* *}$ \\
\hline Debt attit & 0.049 & 0.161 & 0.102 & $0.307^{*}$ \\
\hline Self-cont & -0.131 & -0.109 & 0.269 & 0.122 \\
\hline Self-esteem & -0.136 & 0.111 & 0.263 & -0.133 \\
\hline Sen. Seeking & 0.053 & 0.058 & 0.559 & $0.447^{* *}$ \\
\hline Security & -0.007 & -0.052 & 0.599 & $-0.302^{*}$ \\
\hline
\end{tabular}

\section{Source: Data Analysis}

Table 11: Correlation between revolving debt and civil status

\begin{tabular}{|c|c|c|c|c|}
\hline Factor & $\begin{array}{c}\text { Rev Debt } \\
\text { Married }\end{array}$ & $\begin{array}{c}\text { IntDeb } \\
\text { Married }\end{array}$ & $\begin{array}{c}\text { RevDebt } \\
\text { Single }\end{array}$ & $\begin{array}{c}\text { Inst. } \\
\text { Debt- }\end{array}$ \\
\hline Pow-prest & -0.145 & -0.045 & -0.002 & -0.023 \\
\hline Retention & $.266^{* *}$ & -0.038 & $.356^{*}$ & -0.074 \\
\hline Distrust & $.210^{*}$ & 0.162 & $.352^{*}$ & 0.132 \\
\hline Debt attitude & -0.046 & $.294^{* *}$ & -0.029 & -0.12 \\
\hline Self-control & $-0.231^{*}$ & -0.034 & 0.22 & 0.074 \\
\hline Self esteem & -0.008 & 0.033 & -0.088 & -0.071 \\
\hline Sen. Seeking & 0.069 & $.269^{* *}$ & 0.066 & 0.066 \\
\hline Security & 0.06 & -0.104 & 0.206 & -0.142 \\
\hline
\end{tabular}

Source: Data Analysis

Table 12: Correlation between revolving debt and age

\begin{tabular}{|c|c|c|c|c|}
\hline Factor & $\begin{array}{c}\text { Rev. debt }- \\
\text { age }<35\end{array}$ & $\begin{array}{c}\text { Rev. debt } \\
\text { age }>35\end{array}$ & $\begin{array}{c}\text { Inst. debt }- \\
\text { age }<35\end{array}$ & $\begin{array}{c}\text { Inst. debt }- \\
\text { age }>35\end{array}$ \\
\hline Pow-Pre & -0.014 & -0.108 & $0.401^{*}$ & 0.252 \\
\hline Retention & $.310^{* *}$ & $0.222^{*}$ & 0.127 & -.136 \\
\hline Distrust & $0.275^{* *}$ & 0.171 & 0.051 & -0.042 \\
\hline Debt Att. & -0.004 & $0.198^{*}$ & -0.119 & $0.341^{*}$ \\
\hline Self Con & -0.059 & -0.039 & -0.321 & 0.111 \\
\hline Self estm & 0.059 & 0.073 & -0.140 & -0.029 \\
\hline Sen. Seek & -0.041 & 0.161 & 0.268 & 0.231 \\
\hline Security & 0.146 & -0.097 & -0.061 & -0.099 \\
\hline
\end{tabular}

Source: Data Analysis

Table 13: Correlation between revolving debt and education

\begin{tabular}{|c|c|c|c|c|}
\hline Factor & $\begin{array}{c}\text { Rev. debt }- \\
\text { up to degree }\end{array}$ & $\begin{array}{c}\text { Inst. debt }- \\
\text { up to } \\
\text { degree }\end{array}$ & $\begin{array}{c}\text { Rev.debt- } \\
\text { up to } \\
\text { Postgraduate }\end{array}$ & $\begin{array}{c}\text { Inst. debt }- \\
\text { up to } \\
\text { postgraduate }\end{array}$ \\
\hline Pow -Pre & -.090 & -.022 & -.125 & -.136 \\
\hline Retention & $.262^{* *}$ & -.046 & $0.333^{*}$ & -.050 \\
\hline Distrust & $.279^{* *}$ & .155 & .186 & .148 \\
\hline Debt Atti & .017 & .152 & -.081 & $.294^{*}$ \\
\hline Self Con & -0.091 & 0.34 & -.110 & -.160 \\
\hline Self estm & .124 & -0.26 & $-0.267^{*}$ & 0.134 \\
\hline Sen. Seek & .175 & $.200^{*}$ & -.108 & .236 \\
\hline Security & .084 & -.122 & -.174 & -.107 \\
\hline
\end{tabular}

Source: Data Analysis

Table 14: Correlation between revolving debt and income

\begin{tabular}{|c|c|c|c|c|}
\hline Factor & $\begin{array}{c}\text { Rev.debt } \\
<50,000\end{array}$ & $\begin{array}{c}\text { Ins.Debt } \\
<50,000\end{array}$ & $\begin{array}{c}\text { RevDebt } \\
>50,000\end{array}$ & $\begin{array}{c}\text { InsDebt } \\
>50,000\end{array}$ \\
\hline Pow-Pre & -.133 & .021 & -.094 & -.074 \\
\hline Retention & .326 & .194 & $.289^{* *}$ & -.077 \\
\hline Distrust & $.456^{*}$ & .351 & $.213^{*}$ & .116 \\
\hline Debt Attitude & -.280 & -.032 & .019 & $.242^{*}$ \\
\hline Self-Control & -.172 & -0.089 & -.077 & -.015 \\
\hline Self esteem & -.190 & -.074 & -.012 & 0.041 \\
\hline Sen. seeking & $.416^{*}$ & .217 & 0.130 & $.210^{*}$ \\
\hline Security & -.300 & -.081 & 0.053 & -.125 \\
\hline
\end{tabular}

Source: Data Analysis

Table 15: Correlation between revolving debt andno of cards

\begin{tabular}{|c|c|c|c|c|}
\hline Factor & $\begin{array}{c}\text { Revdebt } \\
\text { Single card } \\
\text { holder }\end{array}$ & $\begin{array}{c}\text { Insdebt } \\
\text { Single } \\
\text { card } \\
\text { holder }\end{array}$ & $\begin{array}{c}\text { Rev. debt } \\
\text { Multiple card } \\
\text { holder }\end{array}$ & $\begin{array}{c}\text { Ins. debt } \\
\text { Multiple } \\
\text { card holder }\end{array}$ \\
\hline Pow-Pre & -.086 & -.095 & -.092 & .047 \\
\hline Retention & $.319^{*}$ & -0.019 & .230 & -.112 \\
\hline Distrust & $.202^{*}$ & .126 & $.273^{*}$ & .159 \\
\hline Debt Attitude & -.040 & .179 & .044 & $.308^{*}$ \\
\hline Self-Control & .011 & -.022 & -.220 & .003 \\
\hline Self esteem & -0.074 & -0.019 & .037 & .105 \\
\hline Sen. seeking & -.011 & 0.145 & .191 & $.361^{* *}$ \\
\hline Security & .113 & -.184 & .093 & .035 \\
\hline
\end{tabular}

Source: Data Analysis

\section{Volume 5 Issue 7, July 2016} www.ijsr.net 


\section{International Journal of Science and Research (IJSR) ISSN (Online): 2319-7064}

Index Copernicus Value (2013): 6.14 | Impact Factor (2015): 6.391

Table 16: Correlation between revolving debt and cr. limit

\begin{tabular}{|c|c|c|c|c|}
\hline Factor & $\begin{array}{c}\text { Rev debt } \\
\text { Cr Limit } \\
<80,000\end{array}$ & $\begin{array}{c}\text { Inst. Debt } \\
\text { Cr Limit } \\
<80,000\end{array}$ & $\begin{array}{c}\text { Rev debt } \\
\text { Cr Limit } \\
>80,000 \\
\text { responds }\end{array}$ & $\begin{array}{c}\text { Inst. Debt } \\
\text { Cr Limit } \\
>80,000 \\
\text { responds }\end{array}$ \\
\hline Pow-Pre & -.104 & -.116 & -.081 & -.061 \\
\hline Retention & .011 & -.102 & $.336^{* *}$ & -.026 \\
\hline Distrust & $.501^{* *}$ & .253 & $.219^{*}$ & .113 \\
\hline Debt Atti & .288 & .253 & -.055 & $.197^{*}$ \\
\hline Self Con & $.360^{*}$ & -.044 & -.161 & -.029 \\
\hline Self estm & -.100 & -.232 & -.028 & .095 \\
\hline Sen. Seek & .302 & .206 & .030 & $.211^{*}$ \\
\hline Security & .250 & .026 & .090 & -.150 \\
\hline
\end{tabular}

Source: Data Analysis
Table 17: Correlation between revolving debt andduration

\begin{tabular}{|c|c|c|c|c|}
\hline Factor & $\begin{array}{c}\text { Rev. } \\
\text { debt }<5 \\
\text { years }\end{array}$ & $\begin{array}{c}\text { Inst. } \\
\text { debt }<5 \\
\text { years }\end{array}$ & $\begin{array}{c}\text { Rev. debt }> \\
5 \text { years }\end{array}$ & $\begin{array}{c}\text { Inst. } \\
\text { debt }>5 \\
\text { years }\end{array}$ \\
\hline Pow -Pres & -.125 & -.097 & -.035 & .052 \\
\hline Retention & $.261^{* *}$ & .003 & $.287^{*}$ & -.187 \\
\hline Distrust & $.239^{*}$ & .186 & .164 & -.016 \\
\hline Debt Attitude & -.045 & .112 & .006 & $.385^{* *}$ \\
\hline Self-Control & -.016 & -.164 & -.233 & .170 \\
\hline Self esteem & 0.089 & .125 & -.059 & -.026 \\
\hline Sen. seeking & -.109 & .110 & .229 & $.335^{*}$ \\
\hline Security & .122 & -.107 & .088 & -.148 \\
\hline
\end{tabular}

\section{Source: Data Analysis}

Table 18: Merchant categories analysis by demographic and socio-economic variables

\begin{tabular}{|c|c|c|c|c|c|c|c|c|c|c|c|c|}
\hline & \multicolumn{3}{|c|}{ Age } & \multicolumn{3}{|c|}{ Gender } & \multicolumn{3}{|c|}{ Civil Status } & \multicolumn{3}{|c|}{ Education } \\
\hline & $\begin{array}{l}35 \text { years } \\
\text { and less } \\
\mathrm{N}=127\end{array}$ & $\begin{array}{c}\text { More than } \\
35 \text { years } \\
\mathrm{N}=34\end{array}$ & Sig & $\begin{array}{c}\text { Male } \\
\mathrm{n}=104\end{array}$ & $\begin{array}{c}\text { Female } \\
\mathrm{N}=57\end{array}$ & Sig. & $\begin{array}{l}\text { Married } \\
\mathrm{n}=117\end{array}$ & $\begin{array}{c}\text { Single } \\
\mathrm{n}=44\end{array}$ & Sig & $\begin{array}{c}\text { Up to } \\
\text { Degree } \\
\text { level } \\
\mathrm{N}=103\end{array}$ & $\begin{array}{c}\text { Post } \\
\text { graduate } \\
\text { and above } \\
\mathrm{N}=58\end{array}$ & Sig \\
\hline Supermarkets & 3.6047 & 3.7188 & .572 & 3.750 & 3.435 & $0.038 *$ & 3.6154 & 3.6591 & .809 & 3.5243 & 3.8103 & .087 \\
\hline Textile and clothing & 3.3488 & .8750 & $.011 *$ & 3.481 & 3.2807 & .124 & 3.4274 & 3.5227 & .611 & 3.3689 & 6034 & .176 \\
\hline Medi & 3.0000 & 6563 & $.006^{* *}$ & 3.0096 & 3.3509 & .091 & 3.3419 & 2.5682 & $000 * *$ & 3.1165 & 3.1552 & .848 \\
\hline Electronic and Durables & 3.0775 & 3.2813 & .354 & 3.0577 & 3.2281 & .353 & 3.1026 & 3.1591 & .774 & 3.1456 & 3.0690 & .675 \\
\hline Hotels and restaurants & 3.2016 & 3.1563 & .840 & 3.2692 & 3.0526 & 247 & 3.2051 & 3.1591 & .819 & 3.1359 & 3.2931 & 399 \\
\hline Education & 2.4884 & 2.1875 & .206 & 2.3558 & 2.5614 & .301 & 2.3162 & 2.7372 & .053 & 2.3689 & 2.5345 & .403 \\
\hline Fuel & 2.4186 & 2.5625 & .600 & 2.6827 & 2.0175 & $0.003 * *$ & 2.6325 & 1.9545 . & $.005^{* *}$ & 2.2330 & 2.8276 & $.008^{*}$ \\
\hline Air Tickets and $t$ & 2.1395 & 2.0625 & .760 & 2.1346 & 2.1053 & .889 & 2.0940 & 2.2045 & .624 & 2.0971 & 2.1724 & .719 \\
\hline ATM & 1.6357 & 1.5000 & .483 & 1.6346 & \begin{tabular}{|l|l|}
6 & 1.5614 \\
\end{tabular} & .650 & 1.5385 & 1.7955 & .137 & 1.5437 & 1.7241 & .261 \\
\hline Utility Bills & 2.5271 & 3.1250 & $.029 *$ & 2.6731 & 2.5965 & .739 & 2.5556 & 2.8864 & .179 & 2.5631 & 2.7931 & .315 \\
\hline Gem \&Jewelers & 1.8837 & 1.7188 & .450 & 1.7692 & 2.0000 & .205 & 1.9316 & 1.6364 & .130 & 1.8835 & 1.7931 & .619 \\
\hline
\end{tabular}

\begin{tabular}{|c|c|c|c|c|c|c|c|c|c|c|c|c|}
\hline & \multicolumn{3}{|c|}{ Income(Rs) } & \multicolumn{3}{|c|}{ Credit Limit(Rs) } & \multicolumn{3}{|c|}{ Duration } & \multicolumn{3}{|c|}{ No of cards } \\
\hline & $\begin{array}{c}\text { Up to } \\
50,000 \\
N=100\end{array}$ & $\begin{array}{l}\text { Above } \\
50,000 \\
\mathrm{~N}=61\end{array}$ & Sig & $\begin{array}{c}\text { Up to } \\
50,000 \\
N=36\end{array}$ & $\begin{array}{l}\text { Above } \\
50,000 \\
\mathrm{~N}=125\end{array}$ & Sig. & $\begin{array}{l}\text { Less than } \\
5 \text { years } \\
\mathrm{N}=104\end{array}$ & $\begin{array}{l}\text { More } \\
\text { than } 5 \\
\text { years } \\
\mathrm{N}=57\end{array}$ & Sig & $\begin{array}{c}\begin{array}{c}\text { Single } \\
\text { card } \\
N=108\end{array} \\
N\end{array}$ & $\begin{array}{c}\text { More than } \\
1 \text { card } \\
\mathrm{N}=53\end{array}$ & sig \\
\hline Supermarkets & 3.6500 & 3.5902 & .719 & 3.3611 & 3.7040 & .075 & 3.4231 & 4.0000 & $000 * *$ & 3.5648 & 3.7547 & .267 \\
\hline Textile and clothing & 3.3900 & 3.5574 & .330 & 3.3611 & 3.4800 & .553 & 3.2115 & 3.8947 & $000 * *$ & 3.4352 & 3.4906 & .755 \\
\hline Hospital bills & 3.0100 & 3.3279 & .111 & 3.8056 & 3.2240 & .071 & 2.9135 & 3.5263 & $.002 * *$ & 3.0093 & 3.3774 & 073 \\
\hline Electronic and Durables & 3.1100 & 3.1311 & .907 & 3.0000 & 3.1520 & .470 & 3.1058 & 3.1404 & .851 & 3.1481 & 3.0566 & .624 \\
\hline Hotels and restaurants & 3.0600 & 3.4098 & .057 & 2.9722 & 3.2560 & .186 & 3.1442 & 3.2807 & .466 & 3.1111 & 3.3585 & .193 \\
\hline Education & 2.400 & 2.4754 & .701 & 2.4444 & 2.4240 & .929 & 2.5865 & 2.1404 & $.024 *$ & 3.4352 & 3.4906 & .755 \\
\hline Fuel & 2.2700 & 2.7377 & $.037 *$ & 2.5278 & 2.4240 & .693 & 2.3365 & 2.6491 & .171 & 2.2222 & 2.9057 & $.003^{* *}$ \\
\hline Air Tickets and travelling & 1.96 & 2.3934 & $.035^{*}$ & 2.1944 & 2.1040 . & .707 & 2.1346 & 2.1053 & .889 & 2.1481 & 2.0755 & .734 \\
\hline ATM & 1.6300 & 1.5738 & .724 & 1.7778 & 1.5600 & .239 & 1.6250 & 1.5789 & .776 & 1.5833 & 1.6604 & .639 \\
\hline Utility Bills & 2.5300 & 2.8361 & .176 & 2.7222 & 2.6240 & .710 & 2.6250 & 2.6842 & .797 & 2.6111 & 2.7170 & .651 \\
\hline Gem \&Jewelers & 1.800 & 1.9344 & .455 & 1.8333 & 1.8560 & .914 & 1.8654 & 1.8246 & .823 & 1.8519 & 1.8491 & .988 \\
\hline
\end{tabular}

\section{Source: Data Analysis}

Table 19: Debt behaviour analysis by demographic and socio economics variables

\begin{tabular}{|c|c|c|c|c|c|c|c|c|c|c|c|c|c|c|c|c|c|c|c|}
\hline & & \multicolumn{3}{|c|}{ Age } & \multicolumn{3}{|c|}{ Gender } & \multicolumn{4}{|c|}{ Civil Status } & \multicolumn{2}{|c|}{ Education } & \multicolumn{3}{|c|}{ Income(Rs) } & \multicolumn{3}{|c|}{ Credit Limit(Rs) } \\
\hline & 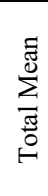 & 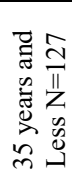 & 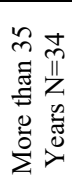 & $\stackrel{.00}{n}$ & $\sum_{\Sigma}^{\frac{0}{\pi}} \frac{\mathbb{0}}{\|}$ & 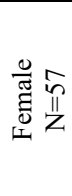 & $\frac{D 0}{\infty}$ & 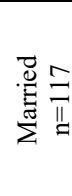 & 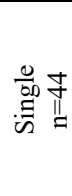 & $\stackrel{\infty}{\infty}$ & 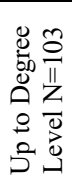 & 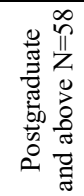 & $\ddot{\infty}$ & 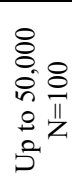 & $\begin{array}{l}8 \\
8 \\
8 \\
n^{\circ} \\
0 \\
0 \\
8 \\
8 \\
8\end{array}$ & $\stackrel{.00}{n s}$ & 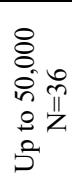 & 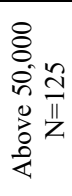 & $\stackrel{\dot{0}}{\omega}$ \\
\hline 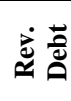 & $\begin{array}{l}\vec{n} \\
\stackrel{n}{n}\end{array}$ & $\begin{array}{l}\frac{n}{n} \\
\hat{n} \\
\dot{n} \\
\dot{n}\end{array}$ & $\underset{n}{\stackrel{n}{n}}$ & $\stackrel{\vartheta}{=}$ & 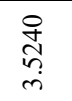 & 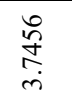 & $\stackrel{8}{1}$ & $\begin{array}{l}\frac{a}{2} \\
\hat{n}\end{array}$ & $\begin{array}{l}\text { ô } \\
\text { శె. } \\
\text { r. }\end{array}$ & $\stackrel{\infty}{\infty}$ & 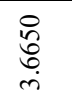 & $\underset{\substack{n \\
f}}{\stackrel{n}{f}}$ & 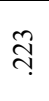 & 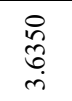 & $\underset{\sim}{\stackrel{q}{\sigma}}$ & $\begin{array}{l}\tilde{D} \\
\stackrel{\infty}{0} \\
0\end{array}$ & $\begin{array}{l}n \\
\hat{b} \\
\dot{n} \\
n\end{array}$ & $\begin{array}{l}\text { ì } \\
\text { i্t } \\
\dot{r}\end{array}$ & ते \\
\hline 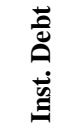 & $\begin{array}{l}\text { तે } \\
\text { הิ }\end{array}$ & 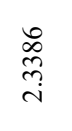 & 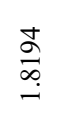 & $\stackrel{*}{\stackrel{*}{0}} \underset{0}{\stackrel{0}{0}}$ & $\begin{array}{l}\underset{ \pm}{ \pm} \\
\stackrel{\Xi}{i}\end{array}$ & $\begin{array}{l}\hat{\hat{s}} \\
\infty \\
i \\
i\end{array}$ & $\stackrel{*}{*}$ & $\begin{array}{l}\text { So } \\
\text { ते } \\
\text { ì }\end{array}$ & $\begin{array}{l}\stackrel{\overbrace{}}{0} \\
\stackrel{\sim}{i}\end{array}$ & $\stackrel{\ominus}{\ni}$ & 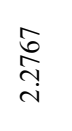 & $\underset{\tilde{n}}{\stackrel{n}{\sim}}$ & 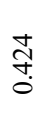 & $\begin{array}{l}\stackrel{8}{0} \\
\text { } \\
\text { ָi }\end{array}$ & 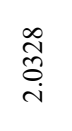 & $\stackrel{2}{\circ}$ & 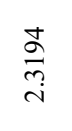 & $\begin{array}{l}\infty \\
\infty \\
\infty \\
\stackrel{\infty}{i}\end{array}$ & $\stackrel{\infty}{\sim}$ \\
\hline
\end{tabular}

Volume 5 Issue 7, July 2016 www.ijsr.net

Licensed Under Creative Commons Attribution CC BY 
International Journal of Science and Research (IJSR)

ISSN (Online): 2319-7064

Index Copernicus Value (2013): 6.14 | Impact Factor (2015): 6.391

\begin{tabular}{|c|c|c|c|c|c|}
\hline \multicolumn{3}{|c|}{ Duration } & \multicolumn{3}{c|}{ No of cards } \\
\hline $\begin{array}{c}\text { Less than 5 years } \\
\mathrm{N}=104\end{array}$ & $\begin{array}{c}\text { More than 5 years } \\
\mathrm{N}=57\end{array}$ & Sig & $\begin{array}{c}\text { Single card } \\
\mathrm{N}=108\end{array}$ & $\begin{array}{c}\text { More than 1 card } \\
\mathrm{N}=53\end{array}$ & sig \\
\hline 3.7572 & 3.3202 & $0.005^{* *}$ & 3.6690 & 3.4670 & .208 \\
\hline 2.3846 & 1.9123 & $0.009^{* *}$ & 2.3102 & 2.0283 & .126 \\
\hline
\end{tabular}

Source: Data Analysis

\section{Conclusions}

This study examined the credit card holders have debt behaviour of revolving debt and instalment plan, and find out whether card holders have specific psychological characteristics. Further study find out those psychological characteristics are relating with the debt behaviour of credit card holders. In addition to that, study is focused on impact of demographic characteristics, security and utility factors for credit card debt behaviour.

Attitude factors of money retention and distrust of money positively related to revolving credit use and instalment plan. These show although card holders have either revolving debt or instalment debt behaviour, they tend to saving money for future usage. Card holders consider credit card transactions as mode of short term financing and realize that saving can be done by paying later (Gurugamage and Wickramasinghe, 2009).

Distrust feature of money attitude correlate with revolving debt and instalment debt significantly, shows that person who could not trust financial transactions, tends to use their credit cards and practice the revolving debt behaviour. Sensation seeking of personality factor positively relates to instalment debt, indicates that people who plan for novelty of life would have instalment plan for credit card.

Moreover, impacts of demographic variables are significant. In addition to that influence of no of cards, credit card usage duration and credit limit are find out. Female revolving debt and instalment plan behaviour are strongly correlated with distrust factor indicates that, females who have distrust characteristics, would be a heavy revolver or heavy instalment plan consumers than males. Females correlation between revolving debtandsecurity features of card transaction, predicts that females tend to use their credit cards for day today transactions more often when security features of credit cards transactions are improved. Female s debt attitude related positively with instalment plan shows that females thinks carrying out some instalment debt is not bad. Therefore this can be influenced to credit card accepting merchants who needs to increase their credit card volume (Figure 1) such as gem and jewellery (2\%), Air tickets and air travelling (4\%), education (6\%). Those merchants can introduce more instalment plans which are specially focused on females. Furthermore correlation of instalment debt and sensation seeking of female are stronger than males. Therefore merchants who can stimulate sensations of life like air tickets and travelling (4\%) and hotels and restaurants (11\%) canintroduce more instalment plan to attract females.

For married people, they take debt as normal deal therefore they would be use their credit cards for daily transaction and keep revolving behaviour and also would keep instalment planning. Married people, sensation seeking negatively related to revolving debt but positively relate to instalment debt. This shows that married people do not find sensation experience of life as day-to-day habit as they have family commitments and busy schedule. But they strongly correlating with instalment plan indicate that married people would become more instalment debtors, as they can manage debt more effectively as instalmentplan has to re-pay by same instalments. Therefore merchants should carefully design their promotions and campaigns based on sensation seeking characteristics of married people.

For people below 35 years old are, take debt as normal deal and can be frequent users of credit cards instalment debt. Age above 35 years are using credit card daily for power and prestige. They might not need it as convenient payment or payment tool, but to show their social status. Younger age group below 35 years old, might no more consider credit card as prestige device as there are many substitutes available in the contemporary society such as smart phones, tabs etc or people might reluctant to bring their credit cardas it is great risk and use it to do card not present transactions. For education, card holders who has education above degree level, more tends to get in to debt for instalment plan, reason for this might be busy schedules of works prevent them daily use credit cards but use them to purchase durables and electronic stuffs for instalment plan. People who use credit cards long period of time (more than 5 years), has significant correlation between debt attitude and instalment plan. This indicates that people, who use credit cards long time, would not use credit cards for daily purchases and do not maintain revolving account.

For people who has credit limit more than Rs. 50,000 has sensation seeking characteristic and debt attitude characteristic related with instalment plan. For Single card holders, debt attitude relate with revolving debt indicate that they can be influenced to use additional credit cards as they consider debt as integral part of life. For multiple card holders debt attitude positively relate with instalment debt indicate that multiple card holders tends to use instalment plan more than revolving debt, this is as they could manage payment process for instalment plan more conveniently than revolving payment.

Respondent's debt behaviour is influenced by demographics and socio economics variables are significant. People who use credit cards more than 5 years, have less usage indicates that people would not frequently consume credit cards long time. Furthermore instalment debt is popular more among female indicates that females are tends to use preplannedinstalment purchases. Younger age groups more influence on pre-plannedinstalment debt significantly where older groups have fewer mean for instalment debt.

Respondents use of credit cards at merchants acquiring are significant for several demographic and socio economic

\section{Volume 5 Issue 7, July 2016 www.ijsr.net}




\section{International Journal of Science and Research (IJSR) \\ ISSN (Online): 2319-7064 \\ Index Copernicus Value (2013): 6.14 | Impact Factor (2015): 6.391}

variables. There are significant differences on making credit card transactions among younger age groups (less than 35 years) and older age groups(more than 35 years) when making payments at textiles and clothing shops, and hospital and utility bill payments. Gender influences significantly in making payments in supermarkets and fuel stations where males are frequently making the credit card payments than females. Civil status of people influences significantly in making credit cards payments at hospitals and fuel stations, where married people frequently use credit cards more than unmarried people. Level of education significantly impact to making credit cards payments at fuel stations where peoples who has postgraduates and above academic qualifications, frequently use credit cards at fuel stations.

The influence of income level is significant in making purchases for airline ticketing and traveling for people who have higher income level (more than Rs. 50,000) are frequently use their credit cards more than lower income level people. The influence of credit card usage duration is significant for makingpayments for super markets textiles and clothing, hospital bills, and education purposes.

People who use credit cards more than 5 years, frequently use their credit cards at supermarkets, purchase garments and paying their medical / hospital bills. On the other hand people who use credit cards less than 5 years, frequently use it for education purposes. Furthermore, there is significant difference in multiple card holders and single card holders credit cards purchases at fuel stations where multiple card holders could make more purchases at fuel stations significantly.

These results should help consumers. Consumer educators should help consumers understand the importance of their attitudes toward money and debt if consumers are attempting to get out of debt. Moreover, educators may need to help consumers to identify their personality traits and to help them focus on the decisions involved in revolving credit use and instalment use.

These findings should also provide implications for commercial banks. Based on demographic variables, bankers can target different groups for their promotional campaigns. In addition to that bankers should examine the personality and attitudes of customers when they provide credit card facilities. Since card holders has retention attitude, bankers can introduce more rewards and raffle draws for their customers to have a feeling of money saving for their future. Card acquiring business has to focus on merchant commission and, card issuing business has to focus on both interchange fee and interest rate. As profit, acquiring bank could gain (commission - interchange fee), while issuing bank depends on interchangefee. Acquiring bankes effort to increase merchant commission depends on negotiates with merchant and maximizes the profit. But due to the competition of card acquiring market, merchants have high negotiation power to get minimum merchant commission. Therefore banks has to focus on card issuing business as people have revolving and instalmentdebtbehaviour, therefore if banks can evaluate their customers personalities and attitudes, they can issue more cards andincreases the frequency of cards usage, will generate high interchange income. Most importantly since card holders have high revolving debt behaviour, card issuing banks can earn high interest revenue.

\section{Limitation and Future Research}

In this research solely investigate credit card users who working as executives in Colombo metropolitan area. In future research data needs to be gathered to represent total population of credit card users of Sri Lanka. It is worth to find out psychological characteristics and socio economic characteristics exist among the non-credit cards debtors also. There are two psychological variables, self-control and selfesteem could not be analyzed as there is low reliability. There needs to be further analysis to find out the reasons for failure of those two variables and further research needs to address that issue.

\section{References}

[1] Afshan, A., Ayesha, A., and Madiha, H. (2009). Consumer Perception and Attitude towards Credit Card Usage: A Study of Pakistani Consumers. Journal Of Comparative International Management,Vol(12), No.1, 47-57.

[2] Arpita, K., Anshuman, K., and Shveta, S. (2011). Factors Affecting Credit Card Use in India Asia Pacific. Journal of Marketing and Logistics, Vol (24) No. 2, 2012 Pp. 236-256

[3] Brito, D. L., and Hartley, P. R. (1995). Consumer Rationality and Credit Cards. The Journal of Political Economy, 103, 400-433.

[4] Chakravorti, S. (2003). "Theory Of Credit Card Networks: A Survey of the Literature" Federal Reserve Bank of Chicago Review of Network Economics, Vol (2), Issue 2 - June 2003.

[5] Chien, Y. W., and Devaney, A. S. (2001). The Effects of Credit Attitude and Socioeconomic Factors on Credit Card and Instalment Debt. Journal of Consumer Affairs, 35(1), 162-179.

[6] Christen, M., and Morgan, R. (2005). Keeping Up With Joneses: Analyzing The Effect Of Income Inequality On Consumer Borrowing. Quantitative Marketing and Economic, 3(2), 145-173.

[7] Garcia, G. (1980). Credit Cards: An Interdisciplinary Survey. The Journal of Consumer Research, 6(4), 327 337.

[8] Emerging Markets Payment Index: Q1 2015. (2015). The Fortumo Emerging Markets Payment Index. Retrieved from

[9] http://www.nfcidea.pl/wpcontent/uploads/2015/05/Emerging-Markets-Q12015.pdf

[10] Grieb, T., Hegji, C., andJones, S. T. (2001). Macroeconomic Factors, Consumer Behaviour, and Bankcard Default Rates. Journal of Economic and Finance, 25(3), 316-327.

[11] Gurugamage, A., andWickramasinghe, V., (2009). Consumer Credit Card Ownership and Usage Practices: Empirical Evidence from Sri Lanka. International Journal of Consumer Studies, 33(4), 436-447.

\section{Volume 5 Issue 7, July 2016 www.ijsr.net}




\section{International Journal of Science and Research (IJSR) \\ ISSN (Online): 2319-7064}

Index Copernicus Value (2013): 6.14 | Impact Factor (2015): 6.391

[12]Hirschman, E. (1979). Differences in Consumer Purchase Behaviour of Credit Card Payment System. Journal of Consumer Research, 6(1), 58-66.

[13] Kwon, K., andLee, J. (2002). Consumers ${ }^{\text {ee }}$ Use of Credit Cards: Store Credit Card Usage as an Alternative Payment and Financing Medium. The Journal of Consumer Affairs, 36, 239-262.

[14]Lili Wang, W. L. (2011). Demographics, Attitude, Personality and Credit Card Features Correlate. Journal of Economic Psychology, 179-193.

[15] Livingstone, M. S., andLunt, K. P. (1992). Predicting Personal Debt and Debt Repayment: Psychological, Social and Economic Determinants. Journal of Economic Psychology, 13(1), 111-134.

[16]Lu, W. N., Malhotra, K., andWang, L., (2010), Demographics, Attitude, Personality and Credit Card Features Correlate with Credit Card Debt.Journal of Economic Psychology, 32 (2011) 179-193

[17] Norvilitis, M. J., Szablicki, P. B., andWilson, D. S. (2003). Factors Influencing Levels of Credit-Card Debt in College Students. Journal of Applied Social Psychology, 33(5), 935-994.

[18]Robb, A. C., andSharpe, D. L. (2009). Effect of Personal Financial Knowledge on College Students ${ }^{\text {ee }}$ Credit Card Behaviour. Journal of Financial Counseling and Planning, 20(1), 25-34.

[19] Tokunaga, H. (1993). The Use and Abuse of Consumer Credit: Application of Psychological Theory and Research. Journal of Economic Psychology, 14, 285316. 